\title{
PERBANDINGAN UMUR SIMPAN BAHAN PAKAN TERNAK YANG DITAMBAHKAN PENGAWET ASAM PROPIONAT DENGAN MODEL PERSAMAAN ARRHENIUS
}

\section{COMPARISON OF STORAGE LIFE OF ANIMAL FEED MATERIALS ADDED WITH PROPIONIC ACID WITH THE ARRHENIUS EQUATION MODEL}

\author{
Rizqa Adisti AZ1a, I Wijayanti, Y Retnaini \\ ${ }^{1}$ Departement of Nutrition Science and Feed Technology, IPB University, Bogor, Indonesia, 16680 Jl. Raya Dramaga, \\ Babakan, Kec. Dramaga, Kota Bogor, Jawa Barat \\ ${ }^{a}$ Korespondensi: Rizqa Adisti , E-mail: rizqaptk233@gmail.com
}

(Diterima oleh Dewan Redaksi: 26 September 2021)

(Dipublikasikan oleh Dewan Redaksi: 31 Oktober 2021)

\begin{abstract}
Estimating the shelf life of feed ingredients is very important to know in order to assist the feed industry in managing storage, availability and maintaining the nutritional quality of the animal feed produced. The purpose of this study was to compare pollard and wheat bran with added propionic acid preservative at different storage temperatures based on the peroxide value using the Arrhenius model. Shelf life was determined by adding propionic acid to pollard and wheat bran and then storing at 15, 35 and $45^{\circ} \mathrm{C}$ for 49 days in an incubator. The parameter used in this research is the peroxide number. The results of this study are based on the calculation of the Arrhenius model. In pollard with propionic acid preservative, it is known that the shelf life at 15,35 and $45{ }^{\circ} \mathrm{C}$ is 38.9 months, 35.6 months and 15.9 months, respectively, while pollard without preservatives is 27.3 months, 22.2 months and 13.1 months. In wheat bran with propionic acid preservative, it is known that the shelf life at 15, 35 and 45 ${ }^{\circ} \mathrm{C}$ is 32.9 months, 21.2 months and 21.2 months, while wheat bran without preservatives is 25.1 months, 15.1 months, and 14.8 months. The conclusion based on the application of the Arrhenius model is that an increase in storage temperature will shorten the shelf life of pollard and wheat bran and the addition of $1 \%$ propionic acid will increase the shelf life of 2.8-13.4 months at a temperature of $15-45^{\circ} \mathrm{C}$ longer than pollard and wheat bran without propionic acid.
\end{abstract}

Key words: Arrhenius, peroxide, pollard, propionic acid, wheat bran.

\begin{abstract}
ABSTRAK
Pendugaan umur simpan pada bahan pakan sangat penting untuk diketahui demi membantu industry pakan dalam mengatur penyimpanan, ketersediaan dan menjaga kualitas nutrisi pakan ternak yang dihasilkan. Tujuan dari penelitian ini adalah untuk membandingkan pollard dan wheat bran yang ditambahkan pengawet asam propionat pada tingkat penyimpanan suhu yang berbeda berdasarkan nilai bilangan peroksida menggunakan model Arrhenius. Umur simpan ditentukan dengan cara, pollard dan wheat bran ditambahkan asam propionat kemudian disimpan pada suhu 15, 35 dan 45 ${ }^{\circ} \mathrm{C}$ selama 49 hari di dalam inkubator. Parameter yang digunakan dalam penelitian ini adalah bilangan peroksida. Hasil penelitian ini didasarkan pada perhitungan model Arrhenius. Pada pollard dengan pengawet asam propionat diketahui umur simpan pada suhu 15, 35 dan $45{ }^{\circ} \mathrm{C}$ berturut turut 38,9 bulan, 35,6 bulan dan 15,9 bulan sedangkan pollard tanpa pengawet berturut turut 27,3 bulan, 22,2 bulan dan 13,1 bulan. Pada wheat bran dengan pengawet asam propionat diketahui umur simpan pada suhu 15,35 dan $45^{\circ} \mathrm{C}$ berturut turut 32,9 bulan, 21,2 bulan dan 21,2 bulan sedangkan pada wheat bran tanpa pengawet beturut turut 25,1 bulan, 15,1 bulan dan 14,8 bulan. Kesimpulan berdasarkan aplikasi model Arrhenius diketahui bahwa peningkatan suhu penyimpanan akan memperpendek umur simpan pollard dan wheat bran dan penambahan asam propionat $1 \%$ akan menambah umur simpan $2,8-13,4$ bulan pada suhu $15-45^{\circ} \mathrm{C}$ lebih lama dibandingkan pollard dan wheat bran tanpa asam propionat.
\end{abstract}

Kata kunci : Arrhenius, asam propionat, peroksida, pollard, wheat bran 
Rizqa Adisti AZ, I Wijayanti, dan Y Retraini. 2021. Perbandingan Umur Simpan Bahan Pakan Ternak Yang Ditambahkan Pengawet Asam Propionat Dengan Model Persamaan Arrhenius Jurnal Peternakan Nusantara 7(2): 89- 96

\section{PENDAHULUAN}

Industry pakan berkembang sangat pesat seiring dengan meningkatnya peternakan khususnya ternak unggas di Indonesia. Peningkatan jumlah produksi pakan tentunya membutuhkan ketersediaan stock bahan pakan yang memiliki mutu dan kualitas yang sesuai dengan standar nutrisi yang diperlukan oleh ternak. Kondisi transportasi di Indonesia yang tidak menentu menyebabkan pabrik gandum melakukan penyimpanan pollard dan wheat bran hal ini tentunya akan menyebabkan fluktuasi keberadaan pollard dan wheat bran. Fluktuasi keberadaan pollard dan wheat bran menyebabkan industri pakan melakukan penyimpanan dalam skala besar sebagai stok bahan pakan untuk proses produksi. Tujuan penyimpanan adalah untuk mempertahankan ketersediaan bahan akan tetapi penyimpanan yang terlalu lama dapat menyebabkan ketengikan sehingga menurunkan mutu bahan. Penurunan mutu bahan pakan akan mempengaruhi mutu produk pakan yang dihasilkan yang akhirnya akan mengurangi kualitas nutrient yang harusnya didapatkan ternak. Hal ini terjadi disebabkan tidak diketahuinya umur simpan dari pollard dan wheat bran sehingga industri pakan kesulitan untuk mengatur stock bahan. Upaya yang dapat dilakukan untuk mengatasi hal ini adalah dengan menentukan umur simpan pollard dan wheat bran.

Penentuan umur simpan dengan metode konvensional memerlukan waktu yang sangat lama untuk itu diperlukan metode yang dapat mempercepat kinetika reaksi dalam pollard dan wheat bran sehingga penentuan umur simpan menjadi lebih singkat. Metode accelerated shelf life testing (ASLT) merupakan jawaban dari masalah ini. Metode ASLT memiliki banyak persamaan antara lain model persamaan Arrhenius. Penentuan umur simpan dengan model persamaan Arrhenius dapat dilakukan dengan cara mengkondisikan lingkungan penyimpanan dengan jarak peningkatan suhu sebesar $10^{\circ} \mathrm{C}$. Peningkatan suhu sebesar $10^{\circ} \mathrm{C}$ diasumsikan sebanding dengan peningkatan reaksi enzimatis yang terjadi dalam bahan pakan. Penyataan ini didukung oleh Hutasoit (2017) yang menyatakan aktivitas enzim lipase tertinggi terjadi pada $\mathrm{pH} 6$ dan suhu inkubasi berpengaruh sangat nyata terhadap aktivitas enzim lipase. Aktivitas enzim lipase tertinggi terjadi pada suhu $45{ }^{\circ} \mathrm{C}$ yaitu $0,102 \mathrm{U} / \mathrm{ml}$ dan terus menurun seiring dengan turunnya suhu inkubasi (Hutasoit 2017).

Ketengikan dapat disebabkan oleh fluktuasi cuaca pada saat penyimpanan yang menyebabkan perubahan suhu dan kelembapan. Peningkatan suhu ini dapat menimbulkan efek berantai seperti peningkatan kadar air yang akan menunjang pertumbuhan kapang, reaksi enzim lipase lebih tinggi akan mempercepat oksidasi yang akhirnya menimbulkan ketengikan, peningkatan sudut tumpukan yang akan mempersulit pengolahan bahan pakan menjadi pakan dan penurunan kerapatan tumpukan yang akan mempersulit packing saat transportasi. Hal ini akhirnya akan menurunkan mutu pollard dan wheat bran. Penurunan mutu menjadi indikator dalam penentuan umur simpan suatu produk. Sehingga diperlukan upaya untuk menghambat proses penurunan mutu tersebut dan menentukan umur simpan dari pollard dan wheat bran tersebut.

Asam propionat merupakan salah satu jenis asam organik yang ditemukan pada tumbuh tumbuhan dan hewan. Cara kerja asam propionate dalam mengawetkan adalah dengan menurunkan $\mathrm{pH}$ produk sehingga mikroba tidak dapat hidup untuk merusak produk. Belum ada standar penggunaan asam propionat pada bahan pakan akan tetapi jika mengacu pada produk antimold yang umumnya digunakan pada pakan dosis nya sebesar $500 \mathrm{~g} /$ ton pakan. Antimold sendiri mengandung $50 \%$ asam propionat (Natalia 2016). Tujuan pada penelitian ini adalah untuk membandingkan pollard dan wheat bran yang ditambahkan pengawet asam propionat pada tingkat penyimpanan suhu yang berbeda berdasarkan nilai bilangan peroksida menggunakan model Arrhenius.

\section{MATERI DAN METODE}

Penelitian ini dilaksanakan di laboratorium Nutrisi Ternak Perah Fakultas Peternakan Institut Pertanian Bogor. Adapun alat yang digunakan dalam penelitian ini antara lain 
inkubator suhu, refrigerator, thermostat, thermometer ruangan, nampan plastik, labu Kjeldahl, labu destilasi, labu erlenmeyer, buret, pipet, heater extract, corong Buchner, kertas saring whatman, gelas ukur, gelas piala dan cawan porselen. Bahan yang digunakan dalam penelitian ini antara lain pollard, wheat bran, asam propionat, n-heksane, Asetat glasial, klorofoorm, $\mathrm{Kl}$ jenuh, iodium, natrium triosulfat, amilum.

Penelitian ini menggunakan metode Accelerate Shelf Life Testing (ASLT) dengan model persamaan Arrhenius. Pengujian dilakukan dengan cara produk disimpan dalam inkubator pada suhu 15,35 dan $45^{\circ} \mathrm{C}$ selama 7 minggu. Pengamatan dilakukan setiap Minggu ke- $0,1,3,5$ dan 7 untuk setiap suhu penyimpanan. Parameter yang diuji untuk pendugaan umur simpan metode ASLT model Arrhenius yaitu menggunakan data bilangan peroksida. Hasil pengamatan bagi setiap parameter penurunan mutu dihitung laju penurunan mutunya per minggu (penurunan unit mutu per minggu atau k) dengan memplotkan dalam grafik hubungan antara nilai ln aktivitas penurunan mutu apabila mengikuti ordo reaksi satu yaitu bilangan peroksida. Sumbu y berupa waktu penyimpanan yaitu hari ke-0, 7, 21, 35 dan 49 dan sumbu $x$ berupa suhu perlakuan 15,35 dan $45^{\circ} \mathrm{C}$

Kemudian dicari nilai $\mathrm{k}$ atau nilai konstanta penurunan mutu per hari yang diperoleh dari kemiringan persamaan regresi kedua grafik tersebut. Setelah diperoleh nilai k, maka dicari nilai $\mathrm{ln} \mathrm{k}$ untuk masing-masing suhu penyimpanan. Selanjutnya dibuat plot Arrhenius, dengan sumbu x menyatakan nilai $1 / \mathrm{T}$ (K-1) dan sumbu y menyatakan nila ln $\mathrm{k}$ pada masingmasing suhu penyimpanan yang digunakan (15, 35 dan $45^{\circ} \mathrm{C}$ ). Nilai k merupakan gradien dari regresi linier yang didapat dari ketiga suhu penyimpanan. Bedasarkan regresi linier yang diperoleh pada kurva Arrhenius ini dapat diprediksi umur simpan produk dengan menggunakan rumus (Salim. 2014):

$$
\mathrm{k}=\mathrm{ko} \cdot \mathrm{e}^{-\mathrm{Ea} / \mathrm{RT}}
$$

Keterangan :

$\mathrm{k}$ : Konstanta penurunan mutu

ko : Konstanta (tidak tergantung pada suhu)

Ea : Energi aktivasi

$\mathrm{T}$ : Suhu mutlak (K)

\section{$\mathrm{R}$ : Konstanta gas $(1.986 \mathrm{kal} / \mathrm{mol} \mathrm{K})$}

Ko merupakan konstanta penurunan mutu produk yang tidak tergantung pada suhu. sedangkan k merupakan konstanta penurunan mutu dari salah satu kondisi suhu yang digunakan (15, 35 dan $45{ }^{\circ}$ C) dan $\mathrm{Ea} / \mathrm{R}$ merupakan gradien yang diperoleh dari plot Arrhenius. Dengan perhitungan menggunakan rumus ini. Maka diperoleh nilai ko. Umur simpan menurut ordo reaksi satu diperoleh dengan rumus (Salim 2014):

$$
\mathrm{t}=\frac{\operatorname{InAo-InAt}}{\mathrm{Ko}}
$$

Keterangan :

$\mathrm{t}$ : Prediksi umur simpan (hari)

Ao : Nilai mutu awal

At : Nilai mutu produk yang tersisa setelah waktu t

\section{ko : Konstanta}

Dari rumus di atas dapat diprediksi umur simpan dalam hari atau bulan.

Penentuan bilangan peroksida diawali dengan pembuatan ekstrak pollard dan wheat bran yang dilakukan dengan teknik maserasi dingin. Pollard dan wheat bran yang telah disimpan di dalam inkubator dengan suhu 15, 35 dan $45{ }^{\circ} \mathrm{C}$ ditimbang 250 gram kemudian dimasukan ke dalam erlenmeyer lalu ditambahkan pelarut n-heksan sampai sample terendam sempuna. Selanjutnya diaduk agar sample tercampur sempurna dan ditutup rapat kemudian dimaserasi pada suhu ruang selama 24 jam. Campuran tersebut diaduk manual setiap 6 jam sekali. selama 5 menit. Setelah Ekstrak bercampur pelarut disaring kasar. Hasil filtrasi kemudian ditampung (filtrat I). Ampas dari filtrat I kemudian ditambahi n-heksan sampai sample terendam sempurna dan dimaserasi kembali selama 24 jam. Kemudian diaduk selama 5 menit dan disaring dengan kertas saring kasar (filtrat II). Filtrat I dan II dicampur dan disaring dengan kertas saring whatman No.1. Filtrat kemudian dievaporasi dengan rotary evaporator pada suhu $40{ }^{\circ} \mathrm{C}$ dengan tekanan $100 \mathrm{mBar}$ untuk menghilangkan pelarut yang terdapat dalam ekstrak sampai semua pelarut habis menguap yang ditandai dengan pelarut tidak menetes lagi dalam jangka waktu minimal 5 menit. Ekstrak kental yang diperoleh dimasukkan ke dalam 
botol sampel (Isadora et al 2016 yang dimodifikasi).

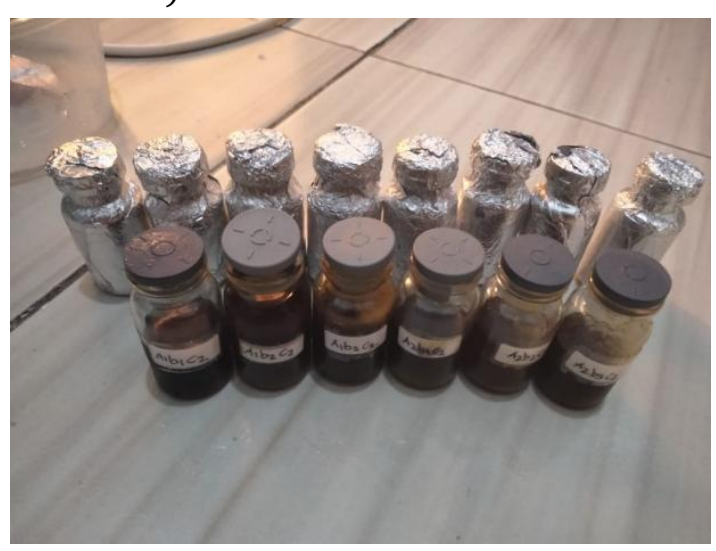

Gambar 1 Ektrak kental pollard dan wheat bran

Penentuan bilangan peroksida digunakan untuk mengetahui konsentrasi ekuivalen peroksida hasil oksidasi lemak dalam sampel (megperoksida/ kg sampel). Sebanyak 5 gram ekstrak dimasukkan ke dalam erlenmeyer tertutup dan ditambahkan $30 \mathrm{~mL}$ pelarut campuran asam asetat glasial : kloroform (3:2 $\mathrm{v} / \mathrm{v})$. Setelah sampel larut sempurna ditambahkan 0,5 $\mathrm{mL}$ larutan $\mathrm{KI}$ jenuh dan dibiarkan 5 menit sambil dikocok, kemudian ditambahkan $30 \mathrm{~mL}$ aquades. Iodium yang dibebaskan oleh peroksida dititrasi dengan larutan standar natrium tiosulfat $\left(\mathrm{Na}_{2} \mathrm{~S}_{2} \mathrm{O}_{3}\right)$ $0,1000 \mathrm{~N}$ dengan indikator amilum sampai warna biru hilang. Bilangan peroksida dinyatakan dengan rumus perhitungan sebagai berikut (Sulieman et al2013):

Bilangan peroksida $=\frac{(\mathrm{mL} \text { titrasi-mL blanko }) \times \mathrm{N} \times 1000}{\text { berat sample }}$

Keterangan: $\mathrm{N} \quad$ : Normalitas $\mathrm{Na}_{2} \mathrm{~S}_{2} \mathrm{O}_{3} 0.01$

\section{HASIL DAN PEMBAHASAN}

Bilangan peroksida berfungsi sebagai indikator kerusakan lemak akibat reaksi oksidasi yang dapat menimbulkan ketengikan pada pakan. Ketengikan erat kaitannya dengan proses oksidasi lemak atau minyak. Proses oksidasi lemak dapat menyebabkan flavor dan aroma yang tidak disukai ternak.

Tabel 1. Nilai bilangan peroksida pada pollard dan wheat bran

\begin{tabular}{|c|c|c|c|c|c|}
\hline \multicolumn{2}{|c|}{ Perlakuan } & \multicolumn{2}{|c|}{$\begin{array}{c}\text { Bilangan peroksida pollard } \\
\left(\mathrm{mEq} \mathrm{O}_{2} / \mathrm{g}\right)\end{array}$} & \multicolumn{2}{|c|}{$\begin{array}{c}\text { Bilangan peroksida wheat bran } \\
\left(\mathrm{mEq} \mathrm{O}_{2} / \mathrm{g}\right)\end{array}$} \\
\hline $\begin{array}{c}\text { Suhu } \\
\text { penyimp } \\
\text { anan }\left({ }^{\circ} \mathrm{C}\right)\end{array}$ & $\begin{array}{c}\text { Waktu } \\
\text { penyimpanan } \\
\text { (hari) }\end{array}$ & $\begin{array}{c}\text { Asam } \\
\text { propionat } \\
1 \%\end{array}$ & $\begin{array}{c}\text { Tanpa asam } \\
\text { propionat }\end{array}$ & $\begin{array}{c}\text { Asam } \\
\text { propionat } \\
1 \%\end{array}$ & $\begin{array}{c}\text { Tanpa asam } \\
\text { propionat }\end{array}$ \\
\hline \multirow{4}{*}{15} & 7 & $0,24 \pm 0,02$ & $0,29 \pm 0,03$ & $0,17 \pm 0,01$ & $0,16 \pm 0,03$ \\
\hline & 21 & $0,54 \pm 0,01$ & $0,62 \pm 0,02$ & $0,18 \pm 0,03$ & $0,23 \pm 0,04$ \\
\hline & 35 & $0,75 \pm 0,03$ & $0,91 \pm 0,01$ & $0,22 \pm 0,02$ & $0,39 \pm 0,05$ \\
\hline & 49 & $0,83 \pm 0,01$ & $1,07 \pm 0,04$ & $0,27 \pm 0,01$ & $0,47 \pm 0,04$ \\
\hline \multirow{4}{*}{35} & 7 & $0,23 \pm 0,05$ & $0,32 \pm 0,03$ & $0,60 \pm 0,02$ & $0,63 \pm 0,04$ \\
\hline & 21 & $0,61 \pm 0,05$ & $0,72 \pm 0,04$ & $0,72 \pm 0,04$ & $0,81 \pm 0,06$ \\
\hline & 35 & $0,76 \pm 0,06$ & $1,08 \pm 0,02$ & $0,84 \pm 0,09$ & $1,03 \pm 0,06$ \\
\hline & 49 & $0,77 \pm 0,07$ & $1,20 \pm 0,01$ & $0,92 \pm 0,07$ & $1,28 \pm 0,04$ \\
\hline \multirow{4}{*}{45} & 7 & $0,52 \pm 0,05$ & $0,63 \pm 0,02$ & $0,61 \pm 0,07$ & $0,68 \pm 0,04$ \\
\hline & 21 & $0,85 \pm 0,07$ & $0,96 \pm 0,03$ & $0,81 \pm 0,06$ & $0,89 \pm 0,05$ \\
\hline & 35 & $0,90 \pm 0,08$ & $1,22 \pm 0,09$ & $0,91 \pm 0,04$ & $1,14 \pm 0,05$ \\
\hline & 49 & $0,97 \pm 0,06$ & $1,38 \pm 0,02$ & $1,02 \pm 0,03$ & $1,43 \pm 0,03$ \\
\hline
\end{tabular}

Berdasarkan Tabel 1 diketahui bahwa terjadi kenaikan bilangan peroksida yang signifikan antara pollard yang ditambahkan asam propionat dengan pollard yang tidak ditambahkan asam propionat. Hal ini disebabkan oleh asam propionat merupakan salah satu jenis asam organik yang berfungsi sebagai pengawet. Bilangan peroksida menunjukkan oksidasi lemak akibat adanya panas dan oksigen. Asam organik bebas yang terdapat pada produk akan dioksidasi oleh oksigen dan panas menjadi peroksida yang merupakan indikator oksidasi awal dari lemak. Pengukuran angka peroksida pada dasarnya adalah mengukur kadar peroksida dan hidroperoksida yang terbentuk pada tahap awal reaksi oksidasi lemak. Bilangan peroksida yang tinggi mengindikasikan lemak 
atau minyak sudah mengalami oksidasi, namun pada angka yang lebih rendah bukan selalu berarti menunjukkan kondisi oksidasi yang masih dini. Angka peroksida rendah bisa disebabkan laju pembentukan peroksida baru lebih kecil dibandingkan dengan laju degradasinya menjadi senyawa lain. Kadar peroksida cepat mengalami degradasi dan bereaksi dengan zat lain (Kaprelyants et al. 2019).

Pada perlakuan penyimpanan pollard tanpa asam propionat pada suhu $45{ }^{\circ} \mathrm{C}$ memiliki nilai peroksida tertinggi yaitu mencapai $1,38 \mathrm{mEg}$ $\mathrm{O}_{2} / \mathrm{g}$ sedangkan pada pollard dengan asam propionate jauh lebih kecil yaitu $0,97 \mathrm{mEg}_{2} / \mathrm{g}$ minyak. Hal ini ditunjang oleh penggunaan cahaya lampu dalam inkubator yang menyebabkan pollard terus tersinari cahaya selama penyimpanan. Tempat penyimpanan pollard yang terbuka dan menggunakan wadah plastik juga mendukung proses oksidasi. Menurut (Kaprelyants et al. 2019). kondisi produk selama waktu tunggu yang terpapar udara bebas mempercepat terjadinya oksidasi lemak oleh oksigen. Proses oksidasi akan mudah terjadi apabila tidak ada antioksidan sebagai zat penghambat.

Pada penelitian ini pollard ditempatkan dalam wadah berbahan plastik sehingga tidak adanya proses antioksidan. Sedangkan pada perlakuan penyimpanan pollard tanpa asam propionate pada suhu $35{ }^{\circ} \mathrm{C}$ memilki nilai bilangan peroksida yang lebih kecil yaitu $1,2 \mathrm{mEg}$ $\mathrm{O}_{2} / \mathrm{g}$ sedangkan pada pollard dengan asam propionate $0,77 \mathrm{mEg} \mathrm{O}_{2} / \mathrm{g}$ minyak. Hal ini ditunjang oleh tempat perlakuan yang tidak disinari cahaya sehingga tidak adanya panas berlebih seperti yang terjadi pada perlakuan suhu $45^{\circ} \mathrm{C}$. Menurut Cong et al (2020) paparan oksigen dan cahaya merupakan faktor utama yang memengaruhi oksidasi dan cahaya merupakan akselerator pertama yang memudahkan oksidasi pada lemak.

Berdasarkan Tabel 1 terlihat bahwa wheat bran dengan perlakuan suhu $45^{\circ} \mathrm{C}$ memiliki nilai peroksida terbesar $(1,43)$ dan wheat bran dengan perlakuan suhu $15{ }^{\circ} \mathrm{C}$ memiliki nilai peroksida terkecil $(0,27)$ hal ini juga terjadi pada perlakuan bilangan peroksida pada pollard. Hal ini menunjukan bahwa perbedaan jenis lemak dari kedua bahan tersebut yang menyebabkan adanya interaksi yang sama dalam proses oksidasi kedua bahan selama penyimpanan yang memengaruhi nilai bilangan peroksida. Meskipun bilangan peroksida tidak dapat membedakan antara berbagai asam lemak tak jenuh yang mengalami oksidasi dan tidak mampu menyediakan informasi tentang produk oksidatif sekunder yang terbentuk dari dekomposisi hiperperoksidanya. Peningkatan bilangan peroksida seiring lamanya penyimpanan menunjukan tahap induksi. dimana terjadinya peningkatan bilangan peroksida dan penurunan sebagai hasil oksidasi lipid. Hidroperoksida rusak pada tingkatan yang lebih cepat daripada pembentukannya dengan kata lain lemak dengan kualitas yang rendah akan memiliki periode induksi yang pendek.

Letak penyusunan sample dalam penelitian ini juga memengaruhi bilangan peroksidanya sebab sample yang dekat dengan cahaya akan lebih cepat teroksidasi dibandingkan dengan sample yang lebih jauh dari cahaya. Senyawa peroksida yang terbentuk dalam proses oksidasi ini juga tidak stabil menurut Cong et al (2020) peningkatan bilangan peroksida selama proses pengorengan akan diikuti oleh penurunan (tidak stabil) karena hidroperoksida yang cenderung terurai pada panas yang tinggi untuk membentuk produk oksidasi sekunder berupa radikal bebas. Oleh sebab itu peneliti menduga bahwa perbedaan bilangan peroksida pollard dan wheat bran pada perlakuan suhu yang sama disebabkan oleh suhu yang tidak selalu stabil selama proses penyimpanan (Tabel 1). Perbedaan letak penyimpanan sample diduga juga memengaruhi hal tersebut.

\section{Aplikasi model Arrhenius}

Model Arrhenius merupakan salah satu model simulasi sederhana untuk menduga laju penurunan mutu produk. Model Arrhenius merupakan pendekatan yang mengkuantifikasi pengaruh suhu terhadap nilai penurunan mutu dan penentuan umur simpan.

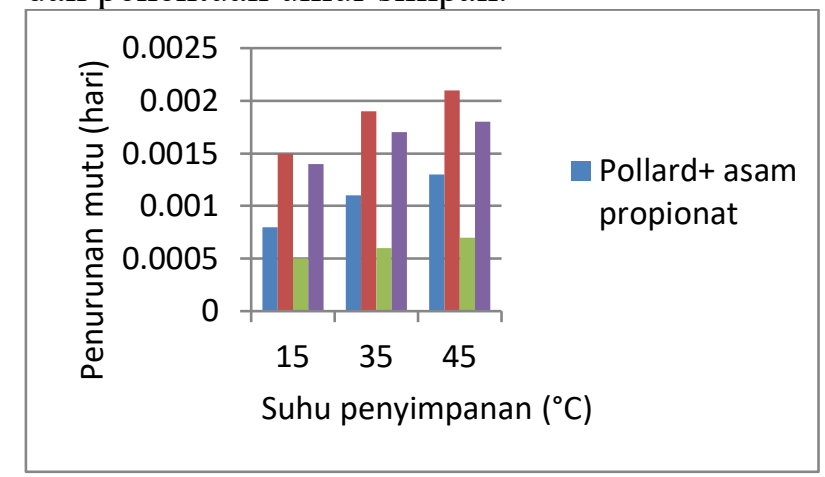

Gambar 2 Grafik perbandingan penurunan mutu bahan pakan dengan atau tanpa pengawet pada suhu penyimpanan berbeda. 
Berdasarkan Grafik 2 diketahui bahwa penurunan mutu akan semakin meningkat seiring dengan peningkatan suhu penyimpanan bahan pakan. Hal ini terjadi disebabkan oleh peningkatan bilangan peroksida (Tabel 1) yang berbanding lurus dengan peningkatan suhu penyimpanan. Penurunan mutu ini terjadi pada semua perlakuan baik pada bahan pakan yang ditambahkan pengawet asam propionat maupun yang tidak ditambahkan akan tetapi jika dianalisis lebih lanjut bahan pakan dengan tambahan asam propionat memiliki penurunan mutu lebih kecil dibandingkan dengan bahan pakan tanpa asam propionat. Hal ini menunjukan asam propionat berpengaruh positif dalam menjaga mutu bahan pakan. Pada grafik juga diketahui penurunan mutu pollard dengan tambahan asam propionat pada suhu 15, 35, dan $45{ }^{\circ} \mathrm{C}$ berturut turut adalah $0,0008 /$ hari, 0,0011 /hari dan 0,0013/hari sedangkan pada pollad tanpa asam propionat berturut turut 0,0015/hari, 0,0019/ hari dan 0,0021/ hari berdasarkan data ini menunjukan bahwa asam propionat mampu menahan penurunan mutu pollard sebesar 0.0007-0.0008/ hari. Penurunan mutu wheat bran dengan tambahan asam propionat pada suhu $15,35,45^{\circ} \mathrm{C}$ berturut turut 0,0005/hari, 0,0006/hari dan 0,0007/hari sedangkan pada wheat bran tanpa asam propionat berturut turut 0,0014/hari, 0,0017/ hari dan 0,0018/ hari berdasarkan data ini menunjukan bahwa asam propionat mampu menahan penurunan mutu wheat bran sebesar 0,0009-0,0011/ hari. Berdasarkan pemaparan diatas dapat disimpulkan bahwa asam propionat bekerja lebih efektif pada wheat bran.

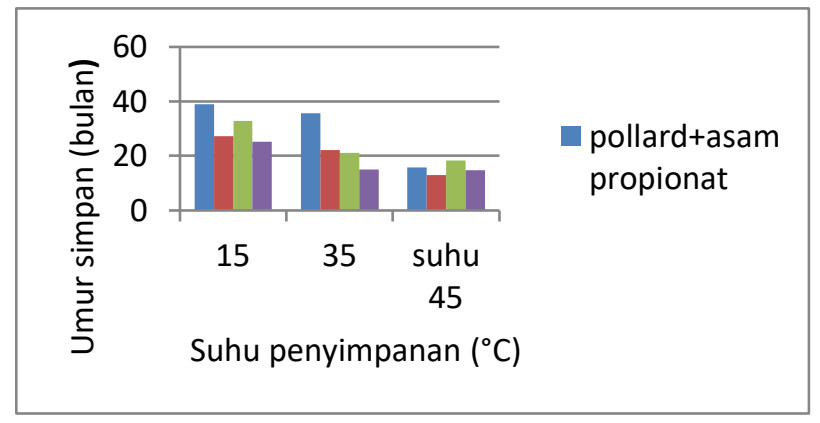

Gambar 3 Grafik perbandingan umur simpan bahan pakan dengan atau tanpa pengawet pada suhu penyimpanan berbeda.

Umur simpan adalah rentang waktu yang dimiliki bahan pakan mulai dari pemanenan hingga di konsumsi sebelum bahan pakan mengalami penurunan mutu/kualitas. Tanggal kadarluarsa (expiration date) merupakan istilah yang sama untuk menggambarkan batasan produk bisa dikonsumsi secara aman dengan kata lain tanggal kadarluarsa (expiration date) lebih menggambarkan tingkat keamanan suatu produk sedangkan umur simpan lebih menggambarkan penurunan kualitas/mutu suatu produk. Berdasarkan Gambar 3 diketahui umur simpan pollard dengan tambahan asam propionat pada suhu 15,35 dan $45^{\circ} \mathrm{C}$ berturut turut adalah 38,9 bulan, 35,6 bulan dan 15,9 bulan sedangkan pollard tanpa asam propionat 27,3 bulan, 22,2 bulan dan 13,1 bulan. Pada wheat bran dengan tambahan asam propionat berturut turut 32,9 bulan, 21, 2 bulan dan 18,4 bulan sedangkan wheat bran tanpa asam propionat 25,1 bulan, 15,1 bulan dan 14,8 bulan. berdasarkan data ini diketahui asam propionat dapat memperpanjang umur simpan pada pollard 11,6-2,8 bulan sedangkan pada wheat bran 7,8-3,6 bulan pada tingkatan suhu $15-45^{\circ} \mathrm{C}$.

Berdasarkan hasil uji Arrhenius pollard dan wheat bran yang ditambahkan asam propionat memiliki umur simpan yang lebih lama dibandingkan pollard dan wheat bran tanpa asam propionat. Hasil ini disebabkan oleh bilangan peroksida pada pollard dan wheat bran yang ditambahkan asam propionat lebih kecil jika dibandingkan dengan kontrol. Menurut Wijayanti (2012) penambahan kalsium propionat dalam bubuk kedelai berpengaruh terhadap aktivitas enzim lipoksigenase. Pemberian panas yang berlebih pada perlakuan suhu $45^{\circ} \mathrm{C}$ selama penyimpanan mengaktifkan enzim lipoksigenase untuk memecah lemak lebih banyak dibandingkan dengan perlakuan suhu dingin $15^{\circ} \mathrm{C}$, akan tetapi dengan adanya ion $\mathrm{Ca}$ pada asam propionat dapat menghambat aktivitas enzim lipoksigenase sehingga ketengikan yang terjadi akibat proses enzimatis dapat terhambat. Menurut Nurani (2020) Asam propionat dapat menghambat aktivitas enzim lipoksigenase, sedangkan perlakuan panas akan meningkatkan aktivitas enzim lipoksigenase. Hal ini yang menjelaskan perbedaan umur simpan pada perlakuan penambahan asam propionat.

Ketengikan juga dapat terjadi akibat adanyanya aktivitas air yang berlebih atau disebut ketengikan hirolisis. Substrat yang ditumbuhi jamur dan kapang biasanya memiliki kadar air yang lebih tinggi. Sebab air 
merupakan media tumbuh kembang mikrobia, adanya asam propionat yang mengendalikan $\mathrm{pH}$ substrat menjadi lebih asam sehingga mikrobia tidak dapat tumbuh tentunya akan mengurangi aktivitas air di dalam substat. Mikrobia sendiri terdiri dari $70 \%$ air dalam selnya dan air merupakan faktor penyebab ketengikan. Kombinasi yang baik antara asam propionat dan suhu penyimpanan akan memperpanjang umur simpan pollard dan wheat bran.

\section{KESIMPULAN DAN IMPLIKASI}

\section{Kesimpulan}

Pemberian ransum yang terdiri atas campuran Pada aplikasi model Arrhenius dapat disimpulkan bahwa peningkatan suhu penyimpanan akan memperpendek umur simpan pollard dan wheat bran dan penambahan asam propionat $1 \%$ dapat memperpanjang masa simpan selama 2,8 - 13,4 bulan lebih lama dari pollard dan wheat bran tanpa asam propionat pada suhu $15-45^{\circ} \mathrm{C}$.

\section{DAFTAR PUSTAKA}

Cong S, Dong W, Zhao J, Hu R, Long Y, Chi X. 2020. Characterization of the lipid oxidation process of robusta green coffee beans and shelf life prediction during accelerated storage. Molecules 25:1-16. DOI: 10.3390/molecules25051157

Hutasoit N. Ina PT. Permana IDG. 2017. Optimasi Ph dan suhu pada aktivitas enzim lipase dari biji kakao (Theobroma cacao L) berkapang. ITEPA. 5(2):95-102

Isadora N K M, Wartini N M, Antara N S. 2016. Pengaruh kombinasi jenis pelarut dan perbandingannya terhadap karakteristik ekstrak buah pandan (Pandanus Tectorius). Rekayasa dan Manajemen Agroind 4: 47-58.

Kaprelyants L, Pozhitkova L, Buzhylov M. 2019. Application of co-bioprocessing techiques (enzymatic hydrolysis and fermentation) for improving the nutritional value of wheat bran as food functional ingrediens. Food Sci Tech 5: 31-45

Natalia D. Suprijatna E. Muryani R. 2016. Pengaruh penggunaan limbah industry jamu dan bakteri asam laktat (Lactobacillus sp) sebagai sinbiotik untuk aditif pakan terhadap performans ayam petelur periode layer. Jurnal ilmu ilmu peternakan. 26(3): 6-13

Nurani V, Widanti Y A. 2020. Pendekatan umur simpan makanan tradisional berbahan dasar beras dengan metode accelerated shelf life testing melalui pendekatan Arrhenius dan kadar air kritis. Argoteknologi.14: 189-198

Salim. M. R. 2014. Aplikasi model Arrhenius untuk pendugaan masa simpan sosis awaym pada penyimpanan dengan suhu yang berbeda berdasarkan nilai TVB Dan pH. [Tesis]. Bandung. Fakultas Pascasarjana. Universitas Pasundan

Sulieman S. Schulze J. Tran LS.2013. Comparative analysis of the symbiotic efficiency of medicago truncatulaand medicago sativa under phosphorus deficiency. International Journal of Molecular Sciences 14.5198-5213

Wijayanti. DN. 2012. Kajian umur simpan bubuk kedelai untuk minuman dengan penambahan kalsium propionat dan perlakuan sterilisasi. [Skripsi]. Teknologi hasil pertanian. Fakultas pertanian. Universitas sebelas maret. Su rakrta. 
